\title{
Preparation and Properties of New Disilane-Containing Polyamide and Polyimides from Diaminodisilanes and Bisphenol Compounds
}

\author{
Munirathina Padmanaban, Masa-aki Kakimoto, and Yoshio Imai* \\ Department of Organic and Polymeric Materials, Tokyo Institute of Technology, \\ Ookayama, Meguro-ku, Tokyo 152, Japan
}

(Received November 13, 1989)

\begin{abstract}
Two new diaminodisilanes, 1,2-bis(diethylamino)tetramethyldisilane and 1,2bis(anilino)tetramethyldisilane were synthesized from 1,2-dichlorotetramethyldisilane and the respective amines. These disilane-containing monomers were reacted with bisphenols containing amide and imide groups, giving disilane-containing polyamide and polyimides which had rather low inherent viscosity around $0.1 \mathrm{dl} \mathrm{g}^{-1}$. The polymers were characterized by UV, IR, and elemental analysis. All the polymers were soluble in $N, N$-dimethylacetamide, dimethyl sulfoxide, $N$ methyl-2-pyrrolidone, and some of them were also soluble in tetrahydrofuran. The polymers had glass transition temperatures between $105-120^{\circ} \mathrm{C}$ and were thermally stable up to $300^{\circ} \mathrm{C}$ in both air and nitrogen atmospheres. A decrease in the moleclar weight was observed upon exposure to UV light indicating the photosensitivity of the disilane-containing polymers.

KEY WORDS Disilane-Containing Polymers / Polyamide / Polyimides / Solubility / Thermal Stability / Photosensitivity /
\end{abstract}

Recently, we have reported the synthesis and properties of new photosensitive polyamides ${ }^{1}$ and polyimides ${ }^{2,3}$ from a disilane-containing diamine, $\operatorname{bis}(p$-aminophenyl)tetramethyldisilane, and various aromatic diacid chlorides and aromatic tetracarboxylic dianhydrides, respectively. These polyamides and polyimides were found to undergo a decrease in inherent viscosity upon exposure to UV light, indicating the silicon-silicon bond scission, and were thermally stable up to $350^{\circ} \mathrm{C}$ with glass transition temperatures $\left(T_{\mathrm{g}}\right)$ around $220^{\circ} \mathrm{C}$. These photosensitive polymers may be promising candidates for thermally stable positive working photoresist materials.

In our further efforts to obtain new thermally stable photosensitive polymers containing disilane unit, we were successful in synthesizing a new series of polymers, poly(oxyaryleneoxydisilane)s, from the bulk polymerization of 1,2-bis(diethylamino)tetramethyldisilane and

\footnotetext{
* To whom all correspondence should be addressed.
}

various bisphenols. ${ }^{4}$ The poly(oxyaryleneoxydisilane)s were thermally stable up to $300^{\circ} \mathrm{C}$, but their glass transition temperatures varied from $-65^{\circ}$ to $135^{\circ} \mathrm{C}$, highly depending on the arylene moiety of the bisphenol component. For example, the polymer possessing rigid and bulky fluorene group was white solid with a $T_{\mathrm{g}}$ of $135^{\circ} \mathrm{C}$, and the polymer with $m$-phenylene unit was a viscous liquid with a $T_{\mathrm{g}}$ of $-65^{\circ} \mathrm{C}$. If these novel photosensitive polymers are to be considered for application as photoresist materials, it is desirable to increase the $T_{\mathrm{g}}$. One easy approach would be to react bisphenols containing amide and imide moieties with above mentioned diaminodisilane. This paper deals with one such attempt in obtaining disilane-containing polymers IIIa - c by the reaction of diaminodisilanes (Ia and b) and bisphenols containing amide (IIa) and imide (IIb and c) groups (eq 1). For comparison, the properties of poly(oxyaryleneoxydisilane) IIId 
obtained previously ${ }^{4}$ by the reaction of Ia and 2,6-dihydroxynapthalene IIc is also included

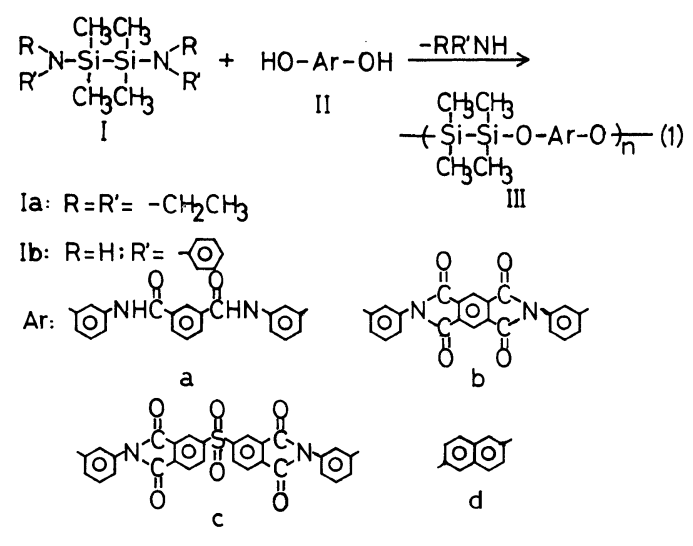

\section{EXPERIMENTAL}

\section{Materials}

1,2-Dichlorotetramethyldisilane was synthesised starting from hexamethyldisilane according to the reported procedure. ${ }^{1}$ Diethylamine, triethylamine, and aniline were dried with calcium hydride and distilled before use. $m$-Aminophenol was recrystallized from water. Isophthaloyl chloride was distilled under reduced pressure. Pyromellitic dianhydride (PMDA), 4,4'-sulfonyldiphthalic dianhydride (DSDA) were purified by sublimation. Solvents such as $m$-cresol, $N, N$-dimethylacetamidé (DMAc), dimethyl sulfoxide (DMSO), $N$ methyl-2-pyrrolidone (NMP), tetrahydrofuran (THF), chloroform, toluene, and benzene were distilled before use.

\section{Monomer Synthesis}

Synthesis of 1,2-bis(diethylamino)tetramethyldisilane (Ia). This compound was prepared by the reaction of 1,2-dichlorotetramethyldisilane with diethylamine in benzene. In a typical reaction, $83.67 \mathrm{~g}(1.14 \mathrm{~mol})$ of diethylamine was placed in a dry three-necked flask fitted with a reflux condenser, a dropping funnel, a mechanical stirrer, and a nitrogen gas inlet along with $600 \mathrm{ml}$ of dry benzene. The mixture was cooled to $0^{\circ} \mathrm{C}$ using an ice bath and to this cold mixture was added a solution of $48.76 \mathrm{~g}$ $(0.26 \mathrm{~mol})$ of 1,2 -dichlorotetramethyldisilane in $100 \mathrm{ml}$ of benzene taken in the dropping funnel, dropwise over a period of $1 \mathrm{~h}$. A white crystalline precipitate began to form almost immediately after the start of the addition of the dichlorosilane. After complete addition, the reaction mixture was stirred at room temperature for $12 \mathrm{~h}$, and then at $100^{\circ} \mathrm{C}$ for $2 \mathrm{~h}$. The white semi-solid reaction mixture thus obtained was filtered to remove the solid diethylamine hydrochloride salt under nitrogen flow. The solvent was distilled out from the filtrate and the crude product was purified by vacuum distillation at $110^{\circ} \mathrm{C} / 11$ Torr. The yield after two repeated distillations was $57.6 \mathrm{~g}(85 \%)$. The IR spectrum (neat) showed absorptions at 2925 and $1251 \mathrm{~cm}^{-1}\left(\mathrm{Si}-\mathrm{CH}_{3}\right)$ and $520 \mathrm{~cm}^{-1}$ (Si-Si). The ${ }^{1} \mathrm{H}$ NMR spectrum measured in $\mathrm{CCl}_{4}$ gave signals at $0.2 \mathrm{ppm}(\mathrm{s}, 12 \mathrm{H}), 1.1 \mathrm{ppm}$ (q, 12), and at $2.8 \mathrm{ppm}(\mathrm{t}, 8 \mathrm{H})$. The UV absorption spectrum in THF showed an absorption maximum $\left(\lambda_{\max }\right)$ at $220 \mathrm{~nm}$ with a molar absorption coefficient $\left(\varepsilon_{\max }\right)$ of $3.13 \times$ $10^{3}$. Anal. Calcd for $\mathrm{C}_{12} \mathrm{H}_{32} \mathrm{~N}_{2} \mathrm{Si}_{2}$ : C, $55.31 \%$, $\mathrm{H}, 12.38 \%$; N, $10.75 \%$. Found: C, $55.09 \%, \mathrm{H}$, $12.08 \%, \mathrm{~N}, 10.59 \%$.

Synthesis of 1,2-bis (anilino) tetramethyldisilane (Ib). To a solution of $9.31 \mathrm{~g}(0.1 \mathrm{~mol})$ of aniline and $11.13 \mathrm{~g}(0.11 \mathrm{~mol})$ of triethylamine in $150 \mathrm{ml}$ of dry benzene was added a solution of $9.36 \mathrm{~g}(0.05 \mathrm{~mol})$ of 1,2-dichlorotetramethyldisilane in $50 \mathrm{ml}$ of benzene at $0^{\circ} \mathrm{C}$ dropwise over a period of $1 \mathrm{~h}$. After complete addition, the reaction mixture was stirred at room temperature for $10 \mathrm{~h}$, and then at $100^{\circ} \mathrm{C}$ for $2 \mathrm{~h}$. The semi-solid reaction mixture thus obtained was filtered to remove the solid triethylamine hydrochloride salt under nitrogen flow. The solvent was distilled off from the filtrate, and the crude product was purified by vacuum distillation at $130^{\circ} \mathrm{C} / 0.1$ Torr. The yield after one distillation was $12 \mathrm{~g}(80 \%)$. The IR spectrum (neat) showed absorptions at 3384 $\mathrm{cm}^{-1}(\mathrm{~N}-\mathrm{H}), 1251 \mathrm{~cm}^{-1}\left(\mathrm{Si}-\mathrm{CH}_{3}\right)$, and 520 $\mathrm{cm}^{-1}(\mathrm{Si}-\mathrm{Si})$. The ${ }^{1} \mathrm{H}$ NMR spectrum gave 
signals at $0.43 \mathrm{ppm}(\mathrm{s}, 12 \mathrm{H}), 3.27(\mathrm{~s}, 2 \mathrm{H})$, and $6.73(\mathrm{~m}, 10 \mathrm{H})$. The UV absorption spectrum in THF showed two absorptions with maxima $\left(\lambda_{\max }\right)$ at $212 \mathrm{~nm}$ and $254 \mathrm{~nm}$ with molar absorptivity $\left(\varepsilon_{\max }\right)$ values of $1 \times 10^{4}$ and $1.95 \times 10^{4}$, respectively. Anal. Calcd for $\mathrm{C}_{16} \mathrm{H}_{24} \mathrm{~N}_{2} \mathrm{Si}_{2}$ : C, 63.94\%, H, 8.05\%, N, $9.32 \%$. Found: C, $63.12 \%, \mathrm{H}, 8.29 \%, \mathrm{~N}$, $9.34 \%$.

Synthesis of $N, N^{\prime}$-bis(m-hydroxyphenyl)isophthalamide (IIa). In a $300 \mathrm{ml}$ three-necked flask were placed $26.19 \mathrm{~g}(0.24 \mathrm{~mol})$ of $\mathrm{m}$ aminophenol and $150 \mathrm{ml}$ of DMAc under nitrogen. To this was added $24.36 \mathrm{~g}(0.12 \mathrm{~mol})$ of isophthaloyl chloride all at once after cooling the solution to $0^{\circ} \mathrm{C}$. The solution was stirred at $6 \mathrm{~h}$ during which time the temperature had risen to room temperature. The reaction mixture was poured into 21 of distilled water and filtered. The filtrate was washed several times with water, and dried under vacuum at $100^{\circ} \mathrm{C}$. The yield was $35.5 \mathrm{~g}(85 \%)$. The compound was recrystallized from an waterethanol mixture ( $1: 1$ by volume), giving white particle like crystals; $\mathrm{mp} 265^{\circ} \mathrm{C}$ (by DTA) (lit. ${ }^{5}$ mp $260-261^{\circ} \mathrm{C}$ ). The IR spectrum (KBr pellet) exhibited absorptions at 3346 and $3308 \mathrm{~cm}^{-1}$ $(\mathrm{O}-\mathrm{H}$ and $\mathrm{N}-\mathrm{H})$, and $1660 \mathrm{~cm}^{-1}(\mathrm{C}=\mathrm{O})$. Anal. Calcd for $\mathrm{C}_{20} \mathrm{H}_{16} \mathrm{O}_{4} \mathrm{~N}_{2}$ : C, 68.95\%; H, 4.63\%, N, $8.04 \%$; Found: C, 68.87\%; H, 4.63\%; N, $7.91 \%$.

Synthesis of $N, N^{\prime}$-bis(m-hydroxyphenyl)pyromellitimide (IIb). In a $500 \mathrm{ml}$ three-necked flask fitted with a nitrogen gas inlet, reflux condenser, and Dien-Stark apparatus were placed $21.81 \mathrm{~g}(0.1 \mathrm{~mol})$ of pyromellitic dianhydride, $21.83 \mathrm{~g}(0.2 \mathrm{~mol})$ of $m$-aminophenol, and $250 \mathrm{ml}$ of $m$-cresol under nitrogen atmosphere. The mixture was stirred at room temperature for $3 \mathrm{~h}$ and then heated to $220^{\circ} \mathrm{C}$ and maintained at that temperature for $3 \mathrm{~h}$. Initially the reaction mixture was heterogeneous but after a reaction time of about $15 \mathrm{~min}$ a homogeneous solution was obtained. The water formed was removed azeotropically, and the remaining $m$-cresol was distilled out under reduced pressure. The reaction mixture was poured into 21 of hexane, and the yellow powder was filtered. The product was washed with hexane, and dried. The yield was $40 \mathrm{~g}(94 \%)$. Recrystallization from a toluene-DMAc $(4: 1$ by volume) mixture afforded yellow color particles; the compound degraded before melting and no clear melting temperature could be observed by DTA. The IR spectrum showed absorptions at $3370 \mathrm{~cm}^{-1}(\mathrm{O}-\mathrm{H})$, and 1780 , and $1720 \mathrm{~cm}^{-1}(\mathrm{C}=\mathrm{O}$, imide). Anal. Calcd for $\mathrm{C}_{22} \mathrm{H}_{12} \mathrm{O}_{6} \mathrm{~N}_{2}: \mathrm{C}, \quad 65.99 \% ; \mathrm{H}, 3.02 \%, \mathrm{~N}$, $6.99 \%$; Found: C, $65.96 \%, \mathrm{H}, 2.92 \%$; $6.89 \%$.

Synthesis of $N, N^{\prime}$-bis(m-hydroxyphenyl)-4,4'sulfonyldiphthalimide IIc. This compound was prepared similar to the method decribed for IIb with an yield of $85 \%$. The compound was used without further purification. No clear melting temperature could be observed by DTA. The IR spectrum of the yellow color compound showed absorptions at $3375 \mathrm{~cm}^{-1}$ $(\mathrm{O}-\mathrm{H}), 1780$ and $1720 \mathrm{~cm}^{-1}(\mathrm{C}=\mathrm{O}$, imide $)$ and $1330 \mathrm{~cm}^{-1}(\mathrm{O}=\mathrm{S}=\mathrm{O})$. Anal. Calcd for $\left(\mathrm{C}_{28} \mathrm{H}_{16} \mathrm{O}_{8} \mathrm{~N}_{2} \mathrm{~S}_{1}\right): \mathrm{C}, 62.22 \% ; \mathrm{H}, 2.98 \% ; \mathrm{N}$, $5.18 \%$; S, 5.93\%; Found: C, $61.79 \%, \mathrm{H}$, $3.18 \%$, N, $5.18 \%$; S, $5.09 \%$.

\section{Polymerization}

A typical example is given for polymer IIIb and the other polymers were prepared in a similar manner.

Synthesis of polymer IIIb from Ib and IIb. In a $50 \mathrm{ml}$ three-necked flask fitted with nitrogen gas inlet and reflux condenser were placed $0.800 \mathrm{~g}(2 \mathrm{mmol})$ of IIb and $0.600 \mathrm{~g}(2 \mathrm{mmol})$ of Ib. To this was added $5 \mathrm{ml}$ of DMAc. The mixture, which was heterogeneous at the begining, turned homogeneous upon heating to $150^{\circ} \mathrm{C}$. After a reaction time of $12 \mathrm{~h}$, the mixture was poured into $500 \mathrm{ml}$ of water and filtered. The polymer was washed with water, and dried. The yield was $1.15 \mathrm{~g}(88 \%)$. The IR spectrum exhibited abosorptions at 1780 and $1720 \mathrm{~cm}^{-1} \quad(\mathrm{C}=\mathrm{O}$, imide $)$, and $1250 \mathrm{~cm}^{-1}$ (Si-O). 


\section{UV Light Irradiation}

$0.1 \mathrm{~g}$ of the sample dissolved in $20 \mathrm{ml}$ of THF was placed in an UV cell. UV light irradiation was carried out using a Toshiba $400 \mathrm{~W}$ high pressure mercury lamp at a distance of $10 \mathrm{~cm}$. The solution temperature was maintained at room temperature by water circulation. After UV light irradiation a portion of the solution was diluted for GPC measurements.

\section{Measurements}

IR spectra and UV spectra were recorded on a JASCO FT/IR-5000 fourier transform spectrophotometer and a Hitachi U-3400 spectrophotometer, respectively. ${ }^{1} \mathrm{H}$ NMR spectra were obrained on a JEOL-PMX 60 NMR spectrometer. Differential thermal analysis (DTA) and thermogravimetry (TG) were performed with Shimadzu thermal analyzers DTA-40M and TG-40M, respectively. Weightaverage $\left(\bar{M}_{w}\right)$ and number-average $\left(\bar{M}_{n}\right)$ molecular weight were obtained by means of GPC on the basis of a polystyrene calibration on a JASCO HPLC BIP-I apparatus (column, Shodex GPC KF-802.5 designed for measurement of molecular weights of the order $10^{3}$; eluent, THF).

\section{RESULTS AND DISCUSSION}

\section{Polymer Synthesis}

The UV absorption spectra of diaminodisilanes Ia and Ib gave absorptions at $\left(\lambda_{\max }\right)$ $220 \mathrm{~nm}$ and $212 \mathrm{~nm}$, respectively, which were assigned to the presence of disilane unit. ${ }^{4}$ The molar absorptivity value $\left(\varepsilon_{\max }\right)$ of Ia was $0.31 \times 10^{4}$ and that of $\mathbf{I b}$ was $1 \times 10^{4}$. The red shift in $\lambda_{\max }$ and higher $\varepsilon_{\max }$ value for $\mathbf{I b}$ compared to Ia may be due to the presence of aniline substituent. Further, Ib showed another absorption maximum at $254 \mathrm{~nm}$ with a $\varepsilon_{\max }$ value of $1.95 \times 10^{4}$ due to the aniline substituent.

First, Ia was reacted with IIa giving polymer IIIa under different reaction conditions to identify optimum reaction parameters (Table
Table I. Synthesis of polymer IIIa from

Ia and IIa under various reaction conditions

\begin{tabular}{|c|c|c|c|c|}
\hline \multicolumn{3}{|c|}{ Reaction conditions $\mathbf{s}^{\mathrm{a}}$} & \multicolumn{2}{|c|}{ Polymer } \\
\hline \multirow{2}{*}{ Solvent } & Temperature & Time & Yield & $\eta_{\mathrm{inh}}^{\mathrm{b}}$ \\
\hline & ${ }^{\circ} \mathrm{C}$ & $\mathrm{h}$ & $\%$ & $\mathrm{dlg}^{-1}$ \\
\hline DMAc & 150 & 12 & 80 & 0.08 \\
\hline DMSO & 150 & 12 & 78 & 0.08 \\
\hline Bulk & $25-240$ & 12 & 95 & 0.11 \\
\hline
\end{tabular}

a Polymerization was carried out with $2 \mathrm{mmol}$ of each monomer in $5 \mathrm{ml}$ of the solvent, and in case of bulk $5 \mathrm{mmol}$ of each monomer was used.

b Measured at a concentration of $0.5 \mathrm{~g} \mathrm{dl}^{-1}$ in DMAc at $30^{\circ} \mathrm{C}$.

I). Mixing of Ia and IIa at room temperature and a gradual increase of temperature to $240^{\circ} \mathrm{C}$ over a period of $2 \mathrm{~h}$ gave a homogeneous reaction mixture and the polymer thus obtained after a reaction time of $10 \mathrm{~h}$ had an inherent viscosity of $0.11 \mathrm{dlg}^{-1}$ (Table I). Our earlier studies on the reaction of Ia with various bisphenols in bulk also yielded polymers with higher inherent viscosity compared to the solution polycondensation. ${ }^{4}$ The bulk reaction of Ia with IIb proceeded heterogeneously and was incomplete due to the high melting temperature of IIb. Hence the polycondensation was carried out in DMAc solution, and the results are summarized in Table II. The polymers had inherent viscosity around $0.1 \mathrm{dl}$ $\mathrm{g}^{-1}$. Polymer IIIa and $\mathbf{c}$ had weight-average molecular $\left(\bar{M}_{w}\right)$ weights of $1.12 \times 10^{4}$ and $1.09 \times 10^{4}$ and number-average molecular $\left(\bar{M}_{n}\right)$ weights of $4.0 \times 10^{3}$ and $5.0 \times 10^{3}$, respectively.

The structures of the polymers were confirmed by means of IR spectroscopy and elemental analysis. The IR spectra of IIIa showed absorptions at $3310 \mathrm{~cm}^{-1}(\mathrm{~N}-\mathrm{H})$, $1660 \mathrm{~cm}^{-1}(\mathrm{C}=\mathrm{O})$, and $1250 \mathrm{~cm}^{-1}(\mathrm{Si}-\mathrm{O})$. The IR spectra of IIIb and $\mathbf{c}$ showed absorptions at $1780 \mathrm{~cm}^{-1}$ and $1720 \mathrm{~cm}^{-1}(\mathrm{C}=\mathrm{O}$, imide $)$ and $1250 \mathrm{~cm}^{-1}(\mathrm{Si}-\mathrm{O})$. The elemental analysis 
Table II. Synthesis of polymers III from I and II $^{\mathbf{a}}$

\begin{tabular}{|c|c|c|c|c|c|c|c|}
\hline & & \multicolumn{6}{|c|}{ Polymer } \\
\hline \multicolumn{2}{|c|}{ Momoners } & \multirow[t]{2}{*}{ Code } & \multirow{2}{*}{$\frac{\text { Yield }}{\%}$} & \multirow{2}{*}{$\frac{\eta_{\mathrm{inh}}^{\mathrm{b}}}{\mathrm{dl} \mathrm{g}^{-1}}$} & \multicolumn{3}{|c|}{ Elemental analysis ${ }^{\mathbf{c}}$} \\
\hline $\mathbf{I}$ & II & & & & $\mathrm{C}(\%)$ & $\mathrm{H}(\%)$ & $N(\%)$ \\
\hline Ia & IIa & IIIa & 85 & 0.08 & $\begin{array}{c}63.28 \\
(62.30)\end{array}$ & $\begin{array}{c}5.16 \\
(5.67)\end{array}$ & $\begin{array}{c}6.30 \\
(6.06)\end{array}$ \\
\hline Ia & IIb & IIIb & 88 & 0.13 & $\begin{array}{c}66.82 \\
(65.51)\end{array}$ & $\begin{array}{c}3.17 \\
(3.78)\end{array}$ & $\begin{array}{c}4.14 \\
(4.78)\end{array}$ \\
\hline Ia & IIc & III $\mathrm{c}^{\mathrm{d}}$ & 80 & 0.10 & $\begin{array}{c}58.23 \\
(58.69)\end{array}$ & $\begin{array}{c}4.01 \\
(4.00)\end{array}$ & $\begin{array}{c}4.06 \\
(4.28)\end{array}$ \\
\hline Ia & IId & IIId $^{e}$ & 95 & 0.59 & $\begin{array}{c}61.34 \\
(61.26)\end{array}$ & $\begin{array}{c}6.81 \\
(6.61)\end{array}$ & - \\
\hline Ib & IIa & IIIa & 92 & 0.11 & & & \\
\hline Ib & IIb & IIIb & 88 & 0.11 & & & \\
\hline Ib & IIc & IIIc & 90 & 0.10 & & & \\
\hline
\end{tabular}

a Polymerizations were carried out by taking $2 \mathrm{mmol}$ of each monomer in $5 \mathrm{ml}$ of DMAc at $150^{\circ} \mathrm{C}$ for $12 \mathrm{~h}$.

b Measured at a concentration of $0.5 \mathrm{~g} \mathrm{dl}^{-1}$ in DMAc at $30^{\circ} \mathrm{C}$.

c The values in the parantheses were the calculated values.

d Polymerization was carried out in $m$-cresol at $220^{\circ} \mathrm{C}$.

e Polymerization was carried out in bulk at $130-260^{\circ} \mathrm{C}$.

Table III. Qualitative solubility of polymers III $^{\mathrm{a}}$

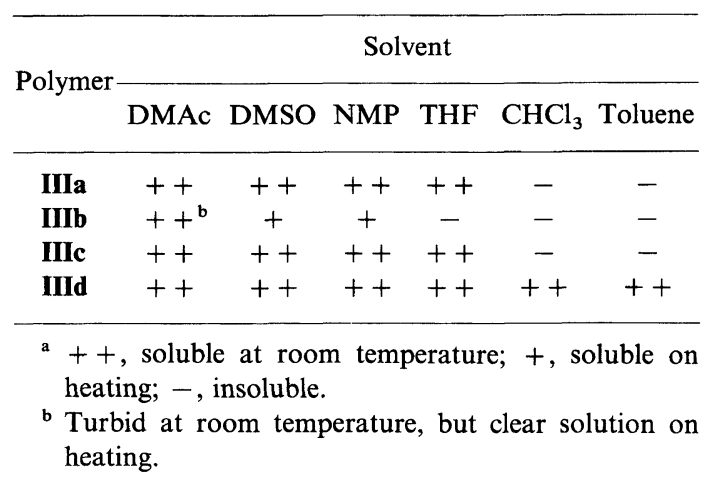

values were in good agreement to the calculated values (Table II).

\section{Polymer Properties}

While polymer IIId was glassy rubber, polymers IIIa - c were hard, brown to yellow solid. The solubility behavior of the polymers is shown in Table III. Polymers IIIa and $\mathbf{c}$ were soluble in DMAc, DMSO, NMP, and THF at room temperature, whereas polymer IIIb was soluble in DMAc, DMSO, and NMP only on

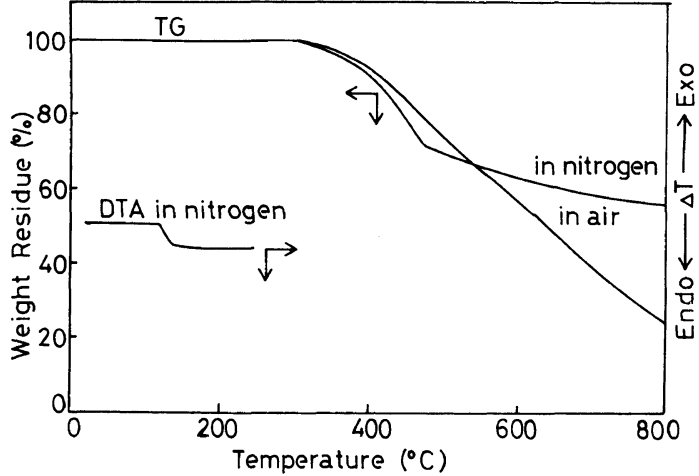

Figure 1. DTA and TG curves of polyimide IIIc at a heating rate of $10^{\circ} \mathrm{C} \mathrm{min}^{-1}$.

heating. Polymers IIIa-c were insoluble in chloroform and toluene. Compared to polymer IIId which was soluble in all the above mentioned solvents, the introduction of the amide and imide moieties decreased the solubility of the polymers.

The thermal behavior of the polymers was evaluated by DTA and TG. A typical example is shown in Figure 1, and the results are summarized in Table IV. Polymers IIIa and c 
Table IV. Thermal behavior data of polymers III

\begin{tabular}{|c|c|c|c|c|c|c|}
\hline \multirow{2}{*}{ Polymer } & \multirow{2}{*}{$\frac{T_{\mathrm{g}}^{\mathrm{a}}}{{ }^{\circ} \mathrm{C}}$} & \multicolumn{2}{|c|}{$T_{\mathrm{i}}^{\mathrm{b}} /{ }^{\circ} \mathrm{C}$} & \multicolumn{2}{|c|}{$T_{10}{ }^{\mathrm{c}} /{ }^{\circ} \mathrm{C}$} & \multirow{2}{*}{$\frac{R_{800}^{\mathrm{d}}}{\%}$} \\
\hline & & In air & In nitrogen & In air & In nitrogen & \\
\hline IIIa & 120 & 330 & 300 & 429 & 427 & 55 \\
\hline IIIb & - & 360 & 351 & 427 & 423 & 54 \\
\hline IIIc & 106 & 343 & 302 & 455 & 439 & 54 \\
\hline IIId & 1 & 352 & 353 & 473 & 444 & 43 \\
\hline
\end{tabular}

a Glass transition temperature determined by DTA at a heating rate of $10^{\circ} \mathrm{C} \mathrm{min}-1$ in nitrogen.

b Temperature of initial weight loss measured by TG at a heating rate of $10^{\circ} \mathrm{Cmin}^{-1}$.

c Temperature at $10 \%$ weight loss measured by TG at a heating rate of $10^{\circ} \mathrm{C} \mathrm{min}{ }^{-1}$.

${ }^{d}$ Residue at $800^{\circ} \mathrm{C}$ in nitrogen.

had glass transition temperatures $\left(T_{\mathrm{g}}\right)$ at 120 and $106^{\circ} \mathrm{C}$, respectively. No glass transition temperature could be detected on DTA and DSC for IIIb. The above mentioned values may not be absolute, because the viscosity and hence the molecular weight values are low. It however shows that the polymers with higher $T_{\mathrm{g}}$ values could be obtained compared to the poly(oxyaryleneoxydisilane)s. Yet, the values are less than those of aramids and polyimides, which are above $200^{\circ} \mathrm{C}$ and this may be due to the presence of flexible $\mathrm{Si}-\mathrm{O}$ units.

The thermal stability of the polymers were studied in both air and nitrogen atmospheres. All the polymers were stable up to $300^{\circ} \mathrm{C}$ with their $10 \%$ weight loss being recorded above $420^{\circ} \mathrm{C}$. The values were less than those of aramids and polyimides and almost comparable to that of IIId, indicating that the thermal break down occurs at the methyl or $\mathrm{Si}-\mathrm{O}$ sites of the disilane units. The residue at $800^{\circ} \mathrm{C}$ under nitrogen atmosphere for polymers IIIa-c was above $50 \%$.

The UV spectrum of polymer IIIa in THF solution showed an absorption at $216 \mathrm{~nm}$ $\left(\varepsilon_{\max }=5.4 \times 10^{4}\right)$ with a shoulder peak at $276 \mathrm{~nm}$. Similarly, IIIc also showed an absorption at $218 \mathrm{~nm}\left(\varepsilon_{\max }=7.8 \times 10^{4}\right)$ with a shoulder peak at $250 \mathrm{~nm}$. Since polymer IIIb was only soluble in hot DMAc, the UV spectra of the spin-coated film was measured, which gave an absorption peak at $220 \mathrm{~nm}$ with a shoulder at $256 \mathrm{~nm}$. The peak around $220 \mathrm{~nm}$ was assigned to the disilane units, and the shoulder peaks to the substituted aromatic benzene rings. The photodegradability of the polymers were tested by measuring the molecular weight of polymer IIIc before and after UV irradiation in THF. The weightaverage molecular $\left(\bar{M}_{w}\right)$ decreased from the initial value of $1.09 \times 10^{4}$ to $1.7 \times 10^{3}$ after a irradiation time of $8 \mathrm{~h}$ indicating the scission of the disilane units present in the polymer backbone, similar to the other disilane containing polymer IIId as well as the aromtic polyamides and polyimides reported previously. ${ }^{1-3}$

\section{REFERENCES}

1. M. Padmanaban, M. Kakimoto, and Y. Imai, $J$. Polym. Sci., A; Polym. Chem., 28, 1569 (1990).

2. M. Padmanaban, M. Toriumi, M. Kakimoto, and Y. Imai, Makromol. Chem. Rapid Commun., 11, 15 (1990).

3. M. Padmanaban, M. Toriumi, M. Kakimoto, and Y. Imai, J. Polym. Sci., A; Polym. Chem., accepted.

4. M. Padmanaban, M. Kakimoto, and Y. Imai, $J$. Polym. Sci., A; Polym. Chem., in press.

5. J. Preston, J. Polym. Sci. A-1, 8, 3135 (1970). 